\title{
Nutritional and care problems in infants with lactose intolerance
}

Department of Pediatrics, Division of Neonatology, Faculty of Health Sciences, Wroclaw Medical University, Wroclaw, Poland IZakład Neonatologii, Katedra Pediatrii, Wydział Nauk o Zdrowiu, Uniwersytet Medyczny we Wrocławiu

CORRESPONDING AUTHOR/AUTOR DO KORESPONDENCJ:

Kinga Tułacz

Katedra Pediatrii, Zakład Neonatologii Wydział Nauk o Zdrowiu, Uniwersytet Medyczny we Wrocławiu

ul. Bartla 5, 51-618 Wrockaw e-mail: kinga.tulacz@umed.wroc.pl

\section{STRESZCZENIE}

Słowa kluczowe:

\section{ABSTRACT}

Key words:

\section{PROBLEMY ZYWIENIOWE I PIELEGNACYJNE U NIEMOWLAT Z NIETOLERANCJA LAKTOZY}

Cel pracy. Celem pracy było poznanie problemów pielęgnacyjnych i żywieniowych u dzieci z nietolerancją laktozy.

Materiał i metodyka. Badaniem objęto grupę 343 rodziców, wśród których znajdowało się 320 (93,3\%) kobiet oraz 23 (6,7\%) mężzzyzn. Do badania wykorzystano kwestionariusz ankiety własnego autorstwa zawierający 27 pytań. Porównanie odpowiedzi w grupach wykonano za pomocą testu chi-kwadrat lub dokładnego testu Fishera tam, gdzie w tabelach pojawiały się niskie liczności oczekiwane. Analizę wykonano w programie R, wersja 4.0.2.

Wyniki. Najczęstszymi objawami dotykającymi dzieci respondentów były: bóle brzucha (77,3\%), wzdęcia brzucha (73,5\%) przelewanie w brzuchu (49\%), stolce z domieszką śluzu (45,5\%). Występujące objawy, aż w 52,5\% były przyczyną niepokoju dziecka podczas snu, w 30,3\% stanowiły problemy z przystawianiem do piersi oraz w 23,9\% powodowały odparzenia pośladków. Analiza statystyczna potwierdziła istotną zależność pomiędzy wykształceniem i wiekiem, a źródłem z którego respondenci czerpali informacje na temat nietolerancji laktozy $(p<0,05)$. Analiza statystyczna wykazała, iż sytuacja materialna nie miała wpływu na suplementację wapnia u kobiet karmiących piersią w czasie stosowania diety bezlaktozowej $(p>0,05)$. Na uwagę jednak zasługuje fakt, iż jedynie 10,5\% respondentów zadeklarowało suplementację wapnia w czasie stosowania diety bezlaktozowej.

Podsumowanie. Istotne jest potwierdzenie diagnozy badaniem, gdyż nietrafna diagnoza może prowadzić do szeregu problemów bez uzyskania oczekiwanego efektu. Wśród dzieci z objawami nietolerancji laktozy kluczowym jest zaspokojenie dziennego zapotrzebowania na wapń.

nietolerancja laktozy, niemowlę, problemy pielęgnacyjne, wapń

Aim. The purpose of the paper was to learn about nursing and nutritional problems in children with lactose intolerance.

Material and methods. The study included a group of 343 parents, 320 (93.3\%) women and 23 (6.7\%) men. A self-written questionnaire containing 27 questions was used for the study. The comparison of responses in the groups was performed using the chi-square test or the Fisher's exact test where the expected low rates appeared in the tables. The analysis was performed in the R software, version 4.0.2.

Results. The most common symptoms affecting the respondents' children were: abdominal pain (77.3\%), abdominal distension (73.5\%), overflow in the abdomen (49\%), and mucus-mixed stools (45.5\%). The symptoms caused the child's anxiety during sleep in $52.5 \%$, problems with attaching to the breast in $30.3 \%$, and buttocks burns in $23.9 \%$. Statistical analysis confirmed a significant relationship between education and age and the source from which the respondents obtained information on lactose intolerance $(p<0.05)$. Statistical analysis showed that the financial situation had no effect on calcium supplementation in breastfeeding women while on a lactose-free diet ( $p>0.05$ ). It is worth noting, however, that only $10.5 \%$ of the respondents declared calcium supplementation while on a lactose-free diet.

Conclusions. It is important to confirm the diagnosis with an examination, as an incorrect diagnosis may lead to a number of problems without obtaining the desired effect. In children with symptoms of lactose intolerance, meeting the daily calcium requirement is essential.

lactose intolerance, infant, care problems, calcium 


\section{INTRODUCTION}

Lactose is an organic carbohydrate compound that occurs naturally in the milk of mammals and is therefore often referred to as milk sugar. It is composed of $\mathrm{D}$-galactose and D-glucose and a $\beta$-1,4-glycosidic bond that connects them. Lactose is broken down into monosaccharides by the action of the lactose-florin hydrolase enzyme (LCT), produced in the apical part of enterocytes, in a brush border called lactase. The activity of lactase differs in individual sections of the intestine, the greatest one is observed in the middle section of the jejunum. Glucose and galactose formed after the breakdown of lactose disaccharide are absorbed in the small intestine and then further metabolized in the liver $[1,2,3]$.

The lactose content in cow's milk is about $4.7 \%$, while in human milk as much as $7.2 \%$ and it is constant, independent of the mother's diet. However, lactose is also found in bread and meat products where it is added to improve taste, flavor or texture $[1,3]$.

The benefits of lactose consumption by newborns include the proper development of the sense of taste and the regulation of appetite, which is due to the fact that lactose is less sweet than glucose or sucrose. The relatively low glycemic index of lactose affects the regulation of hormone secretion. The probiotic properties of lactose have a positive effect on the regeneration processes of intestinal epithelial cells and intestinal motility. The complex of clinical symptoms of the gastrointestinal tract resulting from lactase deficiency is called lactose intolerance $[1,4]$.

The complete or partial lack of lactose hydrolysis, caused by the lack or deficiency of lactase, is the cause of gastrointestinal discomfort. The reason for these ailments is the fact that undigested lactose is consumed by intestinal bacteria, and the products of bacterial fermentation are mainly gases and short-chain organic acids. This situation causes the patient to experience discomfort due to abdominal distension, overflow and colic. Prolonged symptoms can lead to malnutrition and dehydration of the body [4].

There are three clinical forms of lactose deficiency: congenital lactase deficiency, secondary lactase deficiency and primary lactase deficiency. Developmental lactase deficiency is a specific type of lactose intolerance, but it has no clinical significance $[1,3]$.

Congenital lactase deficiency, often called alactasia, is the complete absence of lactase in the human intestine. It is a genetic disease and patients are unable to digest even very small amounts of lactose. After the first administration of breast milk or milk containing lactose, the newborn manifests symptoms in the form of severe diarrhea with watery, acidic stools, and may also be accompanied by vomiting leading to dehydration and malnutrition. It is imperative to follow a lactose-free diet throughout your life. Alactasia is extremely rare, but it is a dangerous disease entity that can even lead to death in the absence of appropriate diagnosis and appropriate therapeutic treatment. In turn, proper dietary management allows the child to develop properly $[1,3,4]$.
Secondary lactase deficiency occurs as a result of damage to the epithelium of the small intestine. Symptoms of intolerance are therefore temporary and disappear with the regeneration of previously damaged intestinal villi. The damage usually occurs in the course of acute gastrointestinal infections, enteropathy or the influence of iatrogenic factors. It can also occur in people who are malnourished, suffer from cystic fibrosis, Crohn's disease and other diseases that may affect the intestinal mucosa $[3,4]$.

Primary lactose deficiency results from the fact that lactase activity decreases with age. The highest activity of lactase is observed in infancy, when mother's milk is the main source of food, then it is systematically reduced and in adulthood the enzyme activity most often accounts for about $10 \%$ of the value determined in infancy. Inheritance occurs in an autosomal recessive manner. It is important that the diagnosis of hypolactasia is not synonymous with the appearance of intolerance symptoms. It is not recommended to completely eliminate lactose from the diet. A dose of around $12 \mathrm{~g}$ of lactose (equivalent to around 250 $\mathrm{ml}$ of cow's milk) is generally well tolerated. In dietary treatment, you can also use lactase preparations (they break down $70-80 \%$ of lactose within $30 \mathrm{~min}$.) and supplementation with probiotic preparations (strains of bacteria with high $\beta$-galactosidase activity), which increase the tolerance of consumed lactose $[1,3,4]$.

Developmental lactase deficiency is a temporary symptom that occurs mainly in newborns born before $34 \mathrm{Hbd}$. Most often, symptoms are transient, do not require treatment and are not clinically significant [1].

We start the diagnosis of lactose intolerance with a carefully collected interview with the patient or his caregiver, but often it will be necessary to perform an auxiliary test. The hydrogen breath test (WTO) is the most commonly used for diagnostic purposes. It consists in the oral administration of a certain amount of lactose (in children $1 \mathrm{~g} / \mathrm{kg}$ b.w., max. $25 \mathrm{~g}$ ) and monitoring the hydrogen concentration in the exhaled air. An attempt at elimination and food provocation is also important, where a diagnostic elimination diet excluding lactose is introduced or supplementation with an exogenous lactase preparation is used. After about 2 weeks of such a diet, the symptoms should disappear and appear after the re-introduction of lactose products to the diet. The oral lactose overload test plays an important role in the diagnosis of children. The essence of the study is the oral administration of lactose in a dose of $2 \mathrm{~g} / \mathrm{kg}$ b.w., and then measurements of blood glucose every 30 minutes (for 2 hours). Other diagnostic methods are: stool $\mathrm{pH}$ testing, direct testing of lactase activity in the biopsy of the small intestinal mucosa. Genetic tests are also important [1].

\section{AIM}

The purpose of the paper was to learn about nursing and nutritional problems in children with lactose intolerance. 


\section{MATERIALS AND METHODS}

The study included a group of 343 parents, 320 (93.3\%) women and 23 (6.7\%) men. A self-written questionnaire containing 27 questions was used for the study. The survey questionnaire consisted of 7 questions in the field of sociodemographic data, the remaining 20 questions concerned the diagnosis, the symptoms experienced by the child and the procedure after the diagnosis of lactose intolerance in the child. The group was selected on a deliberate basis, taking into account only the parents of children diagnosed with lactose intolerance. The survey covered parents from all over the country via the www.survio.com/pl portal. Participation in the study was voluntary. The respondents received full information about the purposefulness of the conducted research and were ensured about anonymity and the possibility of withdrawing from participation in the research at every stage. The study was conducted in accordance with the requirements of the Helsinki Declaration. The study was approved by the Bioethics Committee at the Medical University of Wroclaw. The survey was conducted between 13/12/2019 and 17/07/2020. The survey questions were analyzed by calculating the number and percentage of each response. The comparison of the responses in the groups was performed using the chi-square test (with Yates' correction for $2 \times 2$ tables) or the Fisher's exact test where low expected frequencies appeared in the tables. A significance level of 0.05 was adopted in the analysis. Thus, all $p$ values below 0.05 were interpreted as showing significant relationships. The analysis was performed in the $\mathrm{R}$ program, version 4.0.2 [5].

\section{RESULTS}

Characteristics of the studied group: Age: The most numerous group, i.e. $38.8 \%$, were respondents aged 26-30, respondents aged 31-35 constituted $34.1 \%$, the least numerous group were respondents under 20, constituting $0.6 \%$ of the surveyed group. Gender: Female babies constituted $46.2 \%$, and male babies $-53.8 \%$. Place of residence: $>100,000-45.2 \%$ of the respondents live in the city, $30 \%$ live in a city with less than 100 thousand inhabitants, while $24.8 \%$ live in the countryside. The largest group were respondents with higher education $(71.7 \%)$, followed by secondary education $(22.7 \%)$, then vocational $-5.2 \%$ and primary $-0.3 \%$. Most of the respondents assessed the financial situation as good (44.9\%). When it comes to $31.2 \%$ of the respondents, they described their economic situation as very good, $23.3 \%$ as sufficient and $0.6 \%$ as insufficient.

Analysis of the correlation between the studied variables: Statistical analysis did not show any significant correlation ( $p>0.05$ ) between the place of residence and the recommendations received by the parents of lactose intolerant children from specialists. In all groups, the most common recommendation of specialists was: to continue breastfeeding and to administer lactase exogenously (72.3\%). On the other hand, as many as $30.9 \%$ of respondents were recommended to continue breastfeeding while maintaining a lactose-free diet.
Statistical analysis confirmed a significant relationship between education and the source from which the respondents obtained information on lactose intolerance.

$\mathrm{P}$-values below 0.05 indicate significant differences between the groups. The frequency of choosing the answer "From family" decreased, and the frequency of choosing the answer „From a Certified Lactation Advisor" increased with the level of education (Tab. 1).

Tab. 1. The impact of education on the source from which the respondents obtained their knowledge about lactose intolerance

\begin{tabular}{|l|c|c|c|c|}
\hline $\begin{array}{l}\text { Where did you get the } \\
\text { information on lactose } \\
\text { intolerance and dietary } \\
\text { recommendations? }\end{array}$ & $\begin{array}{c}\text { Basic, } \\
\text { vocational } \\
(\mathbf{N}=19)\end{array}$ & $\begin{array}{c}\text { Secondary } \\
(\mathbf{N}=\mathbf{7 8})\end{array}$ & $\begin{array}{c}\text { Higher } \\
(\mathbf{N}=\mathbf{2 4 6 )}\end{array}$ & \multirow{2}{*}{$\mathbf{p}$} \\
\hline From a pediatrician & $\begin{array}{c}15 \\
(78.95 \%)\end{array}$ & $\begin{array}{c}51 \\
(65.38 \%)\end{array}$ & $\begin{array}{c}155 \\
(63.01 \%)\end{array}$ & $\mathrm{p}=0.369$ \\
\hline $\begin{array}{l}\text { From the community } \\
\text { midwife }\end{array}$ & $\begin{array}{c}6 \\
(31.58 \%)\end{array}$ & $\begin{array}{c}12 \\
(15.38 \%)\end{array}$ & $\begin{array}{c}60 \\
(24.39 \%)\end{array}$ & $\mathrm{p}=0.156$ \\
\hline From a Certified Lactation & $\begin{array}{c}0 \\
\text { Advisor }\end{array}$ & $\begin{array}{c}3 \\
(0.00 \%)\end{array}$ & $\begin{array}{c}30 \\
(3.85 \%)\end{array}$ & $\mathbf{p}=\mathbf{0 . 0 3 3}$ \\
\hline From a dietitian & $\begin{array}{c}1 \\
(5.26 \%)\end{array}$ & $\begin{array}{c}6 \\
(7.69 \%)\end{array}$ & $\begin{array}{c}21 \\
(8.54 \%)\end{array}$ & \multirow{2}{*}{$\mathrm{p}=1$} \\
\hline From parenting sites & $\begin{array}{c}3 \\
(15.79 \%)\end{array}$ & $\begin{array}{c}36 \\
(46.15 \%)\end{array}$ & $\begin{array}{c}102 \\
(41.46 \%)\end{array}$ & $\mathrm{p}=0.053$ \\
\hline From scientific articles & $\begin{array}{c}4 \\
(21.05 \%)\end{array}$ & $\begin{array}{c}28 \\
(35.90 \%)\end{array}$ & $\begin{array}{c}87 \\
(35.37 \%)\end{array}$ & $\mathrm{p}=0.436$ \\
\hline From popular literature & $\begin{array}{c}2 \\
(10.53 \%)\end{array}$ & $\begin{array}{c}9 \\
(11.54 \%)\end{array}$ & $\begin{array}{c}41 \\
(16.67 \%)\end{array}$ & $\mathrm{p}=0.549$ \\
\hline From friends & $\begin{array}{c}5 \\
(26.32 \%)\end{array}$ & $\begin{array}{c}11 \\
(14.10 \%)\end{array}$ & $\begin{array}{c}33 \\
(13.41 \%)\end{array}$ & $\mathrm{p}=0.289$ \\
\hline From family & $\begin{array}{c}6 \\
(31.58 \%)\end{array}$ & $\begin{array}{c}12 \\
(15.38 \%)\end{array}$ & $\begin{array}{c}18 \\
(7.32 \%)\end{array}$ & $\mathbf{p}=\mathbf{0 . 0 0 2 *}$ \\
\hline
\end{tabular}

$\mathrm{p}$ - chi-square test or Fisher's exact test, *Statistically significant relationship $(\mathrm{p}<0.05), \mathrm{N}-$ number of people

The relationship between the age of the respondents and the source from which they learned about the diagnosed lactose intolerance of their child was also statistically significant. P-values below 0.05 indicate significant differences between the groups. The frequency of choosing the answer „From family” decreased with age.

The diagnosis of lactose intolerance was confirmed by testing only in $10.8 \%$ of infants. The most frequently performed test was stool $\mathrm{pH}$ (7.6\% of respondents).

The most common symptoms affecting the respondents' children were: abdominal pain (77.3\%), abdominal distension (73.5\%), overflow in the abdomen (49\%), and mucus-mixed stools (45.5\%). Abdominal pain (68.2\%) and abdominal distension (51.3\%) proved to be the most troublesome for the child. As many as $52.5 \%$ of the symptoms caused the child's anxiety during sleep, $30.3 \%$ were problems with attaching to the breast, and $23.9 \%$ caused buttocks burns.

A small group of respondents (6.4\%) declared that during the expansion of the child's diet - between 6 and 12 months of age, they gave the child a supplement containing calcium, while $21.6 \%$ of parents made sure that the daily calcium requirement was covered with meals during this period. 


\section{DISCUSSION}

According to Czerwionka-Szaflarska et al. [6], if symptomatic secondary lactose intolerance is suspected, appropriate diagnostic tests should be performed to confirm the diagnosis. In infants, stool $\mathrm{pH}$ measurement and elimination and provocation tests are recommended. However, in our own study, only $10.8 \%$ of children underwent a test confirming their diagnosis. The most frequently performed test was stool $\mathrm{pH}$ (7.6\% of the respondents).

Marasz [7] showed no correlation between the incidence of hypolactasia and gender of the respondents in her study. This is confirmed by the analysis of our own research, where $46.2 \%$ were female infants and $53.8 \%$ - male infants.

Additionally, in the studies by Marasz [7], the most common symptoms accompanying a child with diagnosed lactose intolerance were abdominal pain and flatulence. In the analyzed material, the respondents also most often reported abdominal pain and flatulence.

A significant problem of people struggling with the symptoms of lactose intolerance is meeting the daily requirement for calcium. According to Czerwionka-Szaflarska, infants and children in early childhood are particularly exposed to the harmful consequences of calcium deficiency. Lack of adequate calcium supply or its supplementation for a long time in children leads to rickets and failure to achieve optimal peak bone mass [1]. In the study, Baldan et al. showed a statistically significant lower intake of calcium and vitamin D in the studied adolescents with hypolactasia compared to their peers who did not apply dietary restrictions [8]. In own research, only $6.4 \%$ of the respondents declared calcium supplementation for children during the expansion of the diet, while $21.6 \%$ made sure that their children's diet covered the daily requirement for this element.

Nehring-Gugulska emphasizes that lactose in breast milk is produced in the mammary gland by secretory cells, the so-called de novo lactocytes from maternal blood substrates. The lactose content in human milk is constant, independent of the mother's diet [9]. The lack of influence of the mother's diet on the lactose content in her milk is also confirmed by Bravi in his work [10]. In our own study, however, as many as $30.9 \%$ of respondents received a recommendation to follow a lactose-free diet while breastfeeding, which in the light of the above facts seems to be unfounded.

\section{CONCLUSIONS}

The most common symptoms in children with lactose intolerance are abdominal pain and bloating, these are the symptoms that turned out to be the most troublesome for the child and caregivers. Symptoms of intolerance are often the cause of care problems such as buttocks burns or anxiety during sleep and nutritional problems: problems with attaching to the breast, stasis in the breasts, poor weight gain of the child, reluctance to eating. It is also important to confirm the diagnosis with an examination, because an incorrect diagnosis may lead to a number of problems without obtaining the expected effect.

\section{Problemy żywieniowe i pielęgnacyjne u niemowląt z nietolerancją laktozy}

\section{WPROWADZENIE}

Laktoza to organiczny związek z grupy węglowodanów naturalnie występujący w mleku ssaków, często zatem jest nazywana cukrem mlecznym. Zbudowana jest z D-galaktozy i D-glukozy oraz łączącego je wiązania $\beta$-1,4-glikozydowego. Laktoza jest rozkładana na monosacharydy przez działanie enzymu hydrolazy laktozowo-floryzynowej (LCT) wytwarzanego w szczytowych partiach enterocytów, w rąbku szczoteczkowym zwanego laktazą. Aktywność laktazy różni się w poszczególnych odcinkach jelita, największą obserwuje się w odcinku środkowym jelita czczego. Glukoza i galaktoza powstające po rozpadzie dwucukru laktozy ulegają wchłanianiu w jelicie cienkim, a później dalszemu metabolizmowi w wątrobie $[1,2,3]$.

Zawartość laktozy w mleku krowim wynosi ok. 4,7\%, natomiast w mleku kobiecym aż 7,2\% i jest ona stała niezależna od diety matki. Jednakże laktoza znajduje się również $\mathrm{w}$ pieczywie i wyrobach mięsnych, gdzie dodawana jest $w$ celu poprawy smaku, zapachu lub konsystencji $[1,3]$.

Korzyści płynące ze spożywania laktozy przez noworodki to wpływ na prawidłowy rozwój zmysłu smaku oraz regulację łaknienia, co jest spowodowane faktem, iż laktoza jest mniej słodka niż glukoza czy sacharoza. Względnie niski indeks glikemiczny laktozy wpływa na regulacje wydzielania hormonów. Właściwości probiotyczne laktozy wpływają korzystnie na procesy regeneracji komórek nabłonka jelitowego oraz motorykę jelit. Zespół objawów klinicznych ze strony przewodu pokarmowego wynikający $z$ niedoboru laktazy nazywamy nietolerancją laktozy $[1,4]$.

Całkowity lub częściowy brak hydrolizy laktozy, spowodowany brakiem lub niedoborem laktazy jest przyczyną dolegliwości żołądkowo-jelitowych. Powodem tych dolegliwości jest fakt, iż niestrawiona laktoza zostaje zużyta przez bakterie jelitowe, a produkty fermentacji bakteryjnej to przede wszystkim gazy oraz krótkołańcuchowe kwasy organiczne. Sytuacja ta powoduje, że pacjent odczuwa dyskomfort z powodu wzdęć brzucha, przelewań oraz kolek. Przedłużające się dolegliwości mogą prowadzić do niedożywienia i odwodnienia organizmu [4].

Wyróżnia się trzy postacie kliniczne niedoboru laktozy: wrodzony niedobór laktazy, wtórny niedobór laktazy oraz pierwotny niedobór laktazy. Szczególnym rodzajem nietolerancji laktozy jest rozwojowy niedobór laktazy, jednak nie ma on istotnego znaczenia klinicznego $[1,3]$. 
Wrodzony niedobór laktazy, często nazywany alaktazją jest to całkowity brak laktazy w jelicie człowieka. Jest to choroba o podłożu genetycznym, a chorzy nie są zdolni do trawienia nawet bardzo małych ilości laktozy. Już po pierwszym podaniu mleka matki lub mleka zawierającego laktozę noworodek manifestuje objawy w postaci ciężkiej biegunki z wodnistymi, kwaśnymi stolcami, mogą dołączyć się również wymioty prowadzące do odwodnienia i niedożywienia. Konieczne jest stosowanie diety bezlaktozowej przez całe życie. Alaktazja występuje niezwykle rzadko, lecz jest groźną jednostką chorobową, mogącą prowadzić nawet do śmierci w przypadku braku stosownego rozpoznania i odpowiedniego postępowania terapeutycznego. Z kolei odpowiednie postępowanie dietetyczne pozwala dziecku prawidłowo się rozwijać $[1,3,4]$.

Wtórny niedobór laktazy występuje wskutek uszkodzenia nabłonka jelita cienkiego. Objawy nietolerancji mają zatem charakter przejściowy oraz ustępują wraz z regeneracją uprzednio zniszczonych kosmków jelitowych. Do uszkodzeń dochodzi zazwyczaj w przebiegu ostrych zakażeń żołądkowo-jelitowych, enteropatii lub oddziaływania czynników jatrogennych. Może również wystąpić u osób niedożywionych, chorujących na mukowiscydozę, chorobę Leśniowskiego-Crohna i innych chorób mogących mieć wpływ na śluzówkę jelita $[3,4]$.

Pierwotny niedobór laktozy wynika $z$ faktu, iż aktywność laktazy zmniejsza się wraz z wiekiem. Największą aktywność laktazy obserwuje się w okresie niemowlęcym, gdy mleko matki jest głównym źródłem pożywienia, następnie ulega systematycznemu zmniejszaniu i w okresie dorosłości aktywność enzymu stanowi najczęściej ok. 10\% wartości oznaczanej w wieku niemowlęcym. Dziedziczenie występuje w sposób autosomalny recesywny. Ważny jest fakt, iż stwierdzenie hipolaktazji nie jest jednoznaczne z pojawieniem się objawów nietolerancji. Nie zaleca się całkowitej eliminacji laktozy z diety. Uważa się, że dawka ok. 12 g laktozy (równowartość ok. $250 \mathrm{ml}$ mleka krowiego) jest zazwyczaj dobrze tolerowana. W leczeniu dietetycznym zastosować można również preparaty laktazy (w ciągu 30 min. rozkładają 70-80\% laktozy) oraz suplementację preparatami probiotycznymi (szczepy bakterii o wysokiej aktywności $\beta$-galaktozydazy), które zwiększają tolerancję spożytej laktozy $[1,3,4]$.

Rozwojowy niedobór laktazy to przejściowe objawy występujące głównie u noworodków urodzonych przed 34 Hbd. Najczęściej objawy mają charakter przemijający, nie wymagają leczenia i nie mają istotnego znaczenia klinicznego [1].

Diagnostykę nietolerancji laktozy rozpoczynamy od szczegółowo zebranego wywiadu z pacjentem lub jego opiekunem, często jednak potrzebne będzie wykonanie badania pomocniczego. W celach diagnostycznych najczęściej wykorzystuje się wodorowy test oddechowy (WTO). Polega on na podaniu doustnym określonej ilości laktozy (u dzieci 1g/kg m.c., max. 25g) oraz monitorowaniu stężenia wodoru w wydychanym powietrzu. Istotne znaczenie ma również próba eliminacji i prowokacji pokarmowej, gdzie wprowadza się diagnostyczną dietę eliminacyjną z wyłączeniem laktozy lub stosuje suplementację preparatem egzogennej laktazy. Po ok. 2 tygodniach takiej diety objawy powinny ustąpić i pojawić po ponownym wprowadzeniu produktów laktozowych do diety. W diagnostyce dzieci ważną rolę odgrywa test doustnego obciążenia laktozą. Istotą badania jest doustne podanie laktozy w dawce $2 \mathrm{~g} / \mathrm{kg}$ m.c., a następnie pomiarach co $30 \mathrm{~min}$. (przez 2 godziny) stężenia glukozy we krwi. Innymi metodami diagnostycznymi są: badanie pH stolca, bezpośrednie badanie aktywności laktazy w bioptacie błony śluzowej jelita cienkiego. Istotne znaczenie mają również testy genetyczne [1].

\section{CEL PRACY}

Celem pracy było poznanie problemów pielęgnacyjnych i żywieniowych u dzieci z nietolerancją laktozy.

\section{MATERIAŁ I METODYKA}

Badaniem objęto grupę 343 rodziców, wśród których znajdowało się 320 (93,3\%) kobiet oraz 23 (6,7\%) mężczyzn. Do badania wykorzystano kwestionariusz ankiety własnego autorstwa zawierający 27 pytań. Kwestionariusz ankiety składał się z 7 pytań z zakresu danych socjodemograficznych, pozostałe 20 pytań dotyczyło diagnostyki, odczuwanych przez dziecko dolegliwości oraz postępowania po rozpoznaniu u dziecka nietolerancji laktozy. Grupa została skompletowana na zasadzie doboru celowego, uwzględniając wyłącznie rodziców dzieci z diagnozą nietolerancji laktozy. Badaniem zostali objęci rodzice z całego kraju za pośrednictwem portalu www.survio. com/pl. Udział w badaniu był dobrowolny. Respondenci otrzymali pełną informację o celowości prowadzonego badania i zapewnieniu anonimowości oraz możliwości wycofania się z udziału w badaniu na każdym jego etapie. Badanie zostało przeprowadzone zgodnie $\mathrm{z}$ wymogami Deklaracji Helsińskiej. Na przeprowadzenie badania uzyskano zgodę Komisji Bioetycznej przy Uniwersytecie Medycznym we Wrocławiu. Badanie przeprowadzono w terminie 13.12.2019 r. - 17.07.2020 r. Analizę pytań ankietowych przeprowadzono wyliczając liczbę i procent wystąpień każdej z odpowiedzi. Porównanie odpowiedzi w grupach wykonano za pomocą testu chi-kwadrat (z korektą Yatesa dla tabel 2x2) lub dokładnego testu Fishera tam, gdzie w tabelach pojawiały się niskie liczności oczekiwane. W analizie przyjęto poziom istotności 0,05 . A więc wszystkie wartości p poniżej 0,05 interpretowano jako świadczące o istotnych zależnościach. Analizę wykonano w programie R, wersja 4.0.2 [5].

\section{WYNIKI}

Charakterystyka badanej grupy: Wiek: Najliczniejszą grupę, bo $38,8 \%$ stanowili respondenci w przedziale wiekowym 26-30 lat, respondenci w przedziale wiekowym 31-35 lat stanowili 34,1\%, najmniej liczną grupą byli respondenci poniżej 20 roku życia, stanowiąc $0,6 \%$ badanej grupy. Płeć: niemowlęta płci żeńskiej stanowiły $46,2 \%$, natomiast płci męskiej - 53,8\%. Miejsce zamieszkania: w mieście >100 tyś. mieszkańców mieszka 45,2\% respondentów, 30\% zamieszkuje miasto poniżej 100 tyś. 
mieszkańców, natomiast $24,8 \%$ mieszka na wsi. Największą grupę stanowili respondenci z wykształceniem wyższym $(71,7 \%)$, następnie $\mathrm{z}$ wykształceniem średnim $(22,7 \%)$, później zawodowym - 5,2\% i podstawowym $0,3 \%$. Sytuację materialną większość respondentów oceniła jako dobrą (44,9\%). Swoją sytuacje ekonomiczną określiło jako bardzo dobrą 31,2\% respondentów, 23,3\% jako wystarczającą oraz $0,6 \%$ jako niewystarczającą.

Analiza związków pomiędzy badanymi zmiennymi: Analiza statystyczna nie wykazała istotnych zależności (p>0,05) między miejscem zamieszkania, a zaleceniami jakie otrzymywali rodzice dzieci z nietolerancją laktozy od specjalistów. We wszystkich grupach najczęstszym zaleceniem specjalistów było: kontynuacja karmienia piersią oraz podanie egzogennie laktazy (72,3\%). Natomiast, aż 30,9\% respondentów otrzymało zalecenie kontynuacji karmienia piersią $\mathrm{z}$ zachowaniem u siebie diety bezlaktozowej.

Analiza statystyczna potwierdziła istotną zależność pomiędzy wykształceniem, a źródłem z którego respondenci czerpali informacje na temat nietolerancji laktozy. Wartości $\mathrm{p}<0,05$ wskazują na istotne różnice pomiędzy grupami. Częstość wyboru odpowiedzi „Od rodziny” malała, a częstość wyboru odpowiedzi „Od Certyfikowanego Doradcy Laktacyjnego" rosła wraz z poziomem wykształcenia (Tab. 1).

- Tab. 1. Związek wykształcenia badanych ze źródłem, z którego respondenci czerpali wiedzę na temat nietolerancji laktozy

\begin{tabular}{|c|c|c|c|c|}
\hline \multirow{2}{*}{$\begin{array}{c}\text { Skąd czerpała Pani } \\
\text { informacje dotyczące } \\
\text { nietolerancji laktozy } \\
\text { oraz zaleceń } \\
\text { żywieniowych? }\end{array}$} & \multicolumn{3}{|c|}{ Wykształcenie } & \multirow[b]{2}{*}{$\mathbf{p}$} \\
\hline & $\begin{array}{c}\text { Podstawowe, } \\
\text { zawodowe } \\
(\mathrm{N}=19)\end{array}$ & $\begin{array}{l}\text { Średnie } \\
(N=78)\end{array}$ & $\begin{array}{c}\text { Wyższe } \\
(\mathrm{N}=246)\end{array}$ & \\
\hline Od pediatry & $\begin{array}{c}15 \\
(78,95 \%) \\
\end{array}$ & $\begin{array}{c}51 \\
(65,38 \%) \\
\end{array}$ & $\begin{array}{c}155 \\
(63,01 \%) \\
\end{array}$ & $p=0,369$ \\
\hline $\begin{array}{l}\text { Od położnej } \\
\text { środowiskowej }\end{array}$ & $\begin{array}{c}6 \\
(31,58 \%) \\
\end{array}$ & $\begin{array}{c}12 \\
(15,38 \%) \\
\end{array}$ & $\begin{array}{c}60 \\
(24,39 \%) \\
\end{array}$ & $p=0,156$ \\
\hline $\begin{array}{l}\text { Od Certyfikowanego } \\
\text { Doradcy Laktacyjnego }\end{array}$ & $\begin{array}{c}0 \\
(0,00 \%)\end{array}$ & $\begin{array}{c}3 \\
(3,85 \%) \\
\end{array}$ & $\begin{array}{c}30 \\
(12,20 \%) \\
\end{array}$ & $\mathrm{p}=0,033^{*}$ \\
\hline Od dietetyka & $\begin{array}{c}1 \\
(5,26 \%)\end{array}$ & $\begin{array}{c}6 \\
(7,69 \%) \\
\end{array}$ & $\begin{array}{c}21 \\
(8,54 \%) \\
\end{array}$ & $p=1$ \\
\hline Ze stron parentingowych & $\begin{array}{c}3 \\
(15,79 \%) \\
\end{array}$ & $\begin{array}{c}36 \\
(46,15 \%) \\
\end{array}$ & $\begin{array}{c}102 \\
(41,46 \%) \\
\end{array}$ & $\mathrm{p}=0,053$ \\
\hline Z artykułów naukowych & $\begin{array}{c}4 \\
(21,05 \%) \\
\end{array}$ & $\begin{array}{c}28 \\
(35,90 \%) \\
\end{array}$ & $\begin{array}{c}87 \\
(35,37 \%) \\
\end{array}$ & $p=0,436$ \\
\hline Z literatury popularnej & $\begin{array}{c}2 \\
(10,53 \%) \\
\end{array}$ & $\begin{array}{c}9 \\
(11,54 \%) \\
\end{array}$ & $\begin{array}{c}41 \\
(16,67 \%) \\
\end{array}$ & $p=0,549$ \\
\hline Od znajomych & $\begin{array}{c}5 \\
(26,32 \%) \\
\end{array}$ & $\begin{array}{c}11 \\
(14,10 \%) \\
\end{array}$ & $\begin{array}{c}33 \\
(13,41 \%) \\
\end{array}$ & $p=0,289$ \\
\hline Od rodziny & $\begin{array}{c}6 \\
(31,58 \%)\end{array}$ & $\begin{array}{c}12 \\
(15,38 \%)\end{array}$ & $\begin{array}{c}18 \\
(7,32 \%)\end{array}$ & $\mathrm{p}=0,002^{*}$ \\
\hline
\end{tabular}

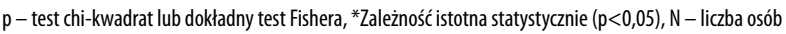

Również istotna statystycznie okazała się zależność wieku respondentów z źródłem $\mathrm{z}$ którego czerpali wiedzę na temat zdiagnozowanej nietolerancji laktozy ich dziecka. Wartości $\mathrm{p}<0,05$ wskazują na istotne różnice pomiędzy grupami. Częstość wyboru odpowiedzi „Od rodziny” malała wraz $\mathrm{z}$ wiekiem.
Diagnoza nietolerancji laktozy została potwierdzona badaniem jedynie u 10,8\% niemowląt. Najczęściej wykonywanym badaniem była ocena $\mathrm{pH}$ stolca $(7,6 \%$ respondentów).

Najczęstszymi objawami dotykającymi dzieci respondentów były: bóle brzucha $(77,3 \%)$, wzdęcia brzucha $(73,5 \%)$, przelewanie w brzuchu (49\%), stolce z domieszką śluzu (45,5\%). Najbardziej uciążliwe dla dziecka okazały się bóle brzucha $(68,2 \%)$ i wzdęcia brzucha $(51,3 \%)$. Występujące objawy, aż w 52,5\% były przyczyną niepokoju dziecka podczas snu, w 30,3\% stanowiły problemy z przystawianiem do piersi oraz w 23,9\% powodowały odparzenia pośladków.

Niewielka grupa respondentów $(6,4 \%)$ deklarowała, że w czasie rozszerzania diety dziecka - między 6 a 12 miesiącem życia podawali dziecku suplement zawierający wapń, natomiast $21,6 \%$ rodziców dbało, aby w tym okresie dzienne zapotrzebowanie na wapń było pokrywane z posiłków.

\section{DYSKUSJA}

Według Czerwionki-Szaflarskiej i wsp. [6] w przypadku podejrzenia objawowej wtórnej nietolerancji laktozy wskazane jest przeprowadzenie odpowiednich badań diagnostycznych, które potwierdzą rozpoznanie. U niemowląt zalecany jest pomiar $\mathrm{pH}$ stolca oraz zastosowanie próby eliminacji i prowokacji. Natomiast w przeprowadzonym badaniu własnym jedynie u 10,8\% dzieci miało wykonane badanie potwierdzające postawioną diagnozę. Najczęściej wykonywanym badaniem była ocena $\mathrm{pH}$ stolca $(7,6 \%$ respondentów).

Marasz [7] w swoim badaniu nie wykazała zależności pomiędzy częstością występowania hypolaktazji, a płcią badanych. Potwierdza to analiza badań własnych, gdzie 46,2\% stanowiły niemowlęta płci żeńskiej i 53,8\% niemowlęta płci męskiej.

Dodatkowo w badaniach Marasz [7] najczęstszymi objawami towarzyszącymi dziecku $z$ rozpoznaną nietolerancją laktozy były bóle brzucha oraz wzdęcia. W analizowanym materiale również respondenci najczęściej podawali ból brzucha i wzdęcia.

Istotnym problemem osób zmagających się z objawami nietolerancji laktozy jest zaspokojenie dziennego zapotrzebowania na wapń. Jak podaje Czerwionka-Szaflarska szczególnie narażone na szkodliwe konsekwencje niedoborów wapnia są niemowlęta i dzieci w okresie wczesnego dzieciństwa. Brak odpowiedniej podaży wapnia lub jego suplementacji przed dłuższy czas u dzieci prowadzi do krzywicy oraz nieosiągnięcia optymalnej szczytowej masy kostnej [1]. Baldan i wsp. w badaniu wykazali istotne statystycznie niższe spożycie wapnia i witaminy D u badanej młodzieży $\mathrm{z}$ hipolaktazją w porównaniu do rówieśników nie stosujących restrykcji dietetycznych [8]. W badaniach własnych jedynie $6,4 \%$ respondentów zadeklarowała suplementowanie wapnia dzieciom w czasie rozszerzania diety, natomiast $21,6 \%$ dbało o to, aby dieta ich dzieci pokrywała dzienne zapotrzebowanie na ten pierwiastek.

Nehring-Gugulska podkreśla, iż laktoza w mleku kobiecym jest wytwarzana w gruczole piersiowym, przez 
komórki wydzielnicze tzw. laktocyty de novo z substratów pochodzących z krwi matki. Zawartość laktozy w pokarmie kobiecym jest stała, niezależna od diety matki [9]. Brak wpływu diety matki na zawartość laktozy w jej mleku potwierdza również Bravi w swej pracy [10]. W badaniu własnym natomiast, aż 30,9\% respondentów otrzymało zalecenie przestrzegania diety bezlaktozowej w czasie karmienia piersią, co w świetle powyższych faktów wydaje się być bezzasadne.

\section{PODSUMOWANIE}

Najczęstszymi objawami u dzieci z nietolerancją laktozy są bóle oraz wzdęcia brzucha, są to objawy, które jednocześnie okazały się najbardziej uciążliwe dla dziecka i jego opiekunów. Objawy nietolerancji często są przyczyną problemów pielęgnacyjnych takich jak odparzenie pośladków czy niepokój podczas snu oraz żywieniowych: problemy z przystawieniem do piersi, zastoje w piersiach, słabe przyrosty masy ciała dziecka, niechęć do jedzenia. Istotne jest również potwierdzenie diagnozy badaniem, gdyż nietrafna diagnoza może prowadzić do szeregu problemów bez uzyskania oczekiwanego efektu.

\section{ORCID}

Kinga Tułacz (DD https://orcid.org/0000-0003-0476-4422

Anna Rozensztrauch (D) https://orcid.org/0000-0003-1727-3235

Marta Berghausen-Mazur (iD https://orcid.org/0000-0002-0119-7699

\section{REFERENCES/PIŚMIENNICTWO}

1. Czerwionka-Szaflarska M, Rekowska M. Czy pamiętamy, jak ważna jest laktoza w diecie niemowląt i małych dzieci. Standardy medyczne, Pediatria. 2018;15;787-796.

2. Fidler-Witoń E, Mądry E, Krasińska B, Walkowiak J. Nietolerancja laktozy i jej uwarunkowania. Family Medicine \& Primary Care Review. 2011;13(2):308-310.

3. Rychlik U, Marszałek A. Nietolerancja laktozy - współczesny stan wiedzy. Diagnostyka laboratoryjna. 2013; 49(1):71-73.

4. Zatwarnicki P. Nietolerancja laktozy - przyczyny, objawy, diagnostyka. Piel. Zdr. Publ. 2014; 4(3):273-276.

5. R Core Team (2020). R: A language and environment for statistical computing. R Foundation for Statistical Computing, Vienna, Austria. URL https://www.R project.org/.

6. Czerwionka-Szaflarska M, Adamska I. Ostra biegunka u dzieci - najnowsze wytyczne. Forum Medycyny Rodzinnej. 2009; 3(6):431-438.

7. Marasz A. Częstość i obraz kliniczny hypolaktazji u dzieci, młodzieży i studentów ze Szczecina. Pom J Life Sci. 2015;61(2):207-213.

8. Baldan A, Tagliati S, Saccomandi D, i wsp. Assesment of Lactose-Free Diet on the Phalangeal Bone Mineral Status in Italian Adolescents Affected by Adult-Type Hypolactasia. Nutrients. 2018;10:558.

Manuscript received/Praca zgłoszona do czasopisma: 10.08.2020

Manuscript accepted/Praca zaakceptowana do druku: 17.09.2020

Translation/Tłumaczenie: Mariola Dyl, Biuro Tłumaczeń Online - Blanka 